\title{
UPDATING THE EXISTING APPROACHES TO GAUGING THE LENGTH OF OPERATING AND CASH CONVERSION CYCLES
}

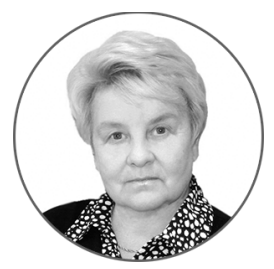

Article history:

Received 28 June 2018

Received in revised form

12 July 2018

Accepted 23 July 2018

Translated 3 September 2018

Available online 28 September 2018

JEL classification: 012, 001

Keywords: operating cycle, cash conversion cycle, calculation algorithm

\author{
Glafira V. SAVITSKAYA \\ Belarus State Economic University (BSEU), Minsk, Republic of Belarus \\ glafira.savickaja@mail.ru \\ ORCID: not available
}

\begin{abstract}
Importance Operating and cash conversion cycles are one of the key performance indicators of working capital management. If they last longer, more working capital is required, while their decrease has the opposite effect. The duration measurement methodology is a frequent subject of discussion in the scholarly and training literature. However, there are dissenting opinions on their substance and measurement technique.

Objectives The research comprehensively studies challenging aspects of the methodology for measuring the duration of operating and cash conversion cycles and substantiates my own viewpoint on the issues.

Methods The theoretical and methodological framework comprises proceedings of the national and foreign economists majoring in financial analysis. I also use the historical approach, generic and special methods of analysis, synthesis and analogy.

Results I specify the economic substance and technique to gauge the duration of operating and cash conversion cycles and their constituents. To make the computations more precise, it is advisable to estimate inventories, receivables and payables using monthly or even daily balances, which are quite feasible as accounting and analytical data are processed electronically.

Conclusions and Relevance The proposed approach may serve as a basis for further development of the financial analysis methodology and methodological guide for business entities to monitor and make business decisions in the process of working capital management.
\end{abstract}

The operating cycle means a period of time, during which working capital makes the entire turn in operations (procurement, production and distribution). During the operating cycle, business entities purchase inventories, manufacture finished goods and sell them for cash or on credit, and clients repay their amounts due. In other words, it is the average time between the acquisition of

${ }^{\dagger}$ For the source article, please refer to: Савицкая Г.В. Актуализация существующих подходов к определению продолжительности операционного и финансового циклов. Экономический анализ: теория и практика. 2018. Т. 17. № 8. С. 1564-1583. URL: https://doi.org/10.24891/ea.17.8.1564 resources and materials and collecting cash from the sale of products, goods and services.

The operating cycle consists of:

- inventory period, that is the amount of time which starts as inventories are entered for storage and ends when finished goods are shipped to buyers;

- accounts receivable period, that is the period of time when buyers repay their debts arising from purchases on credit.

Most authors advocate this particular concept for determining the substance of the operating cycle.

Please cite this article as: Savitskaya G.V. Updating the Existing Approaches to Gauging the Length of Operating and Cash Conversion 
However, there are still other opinions in some publications.

For instance, many definitions commonly falter by qualifying the duration of the operating cycle as the time required for money to convert from the moment of being invested in inventories till the moment it is recovered as revenue form products sold $[1$, p. $275 ; 2$, p. $10-15 ; 3$, p. 30; 4, p. 205].

According to the definition, the operating cycle is fed with monetary capital. In fact, it depends not only on monetary funds, but also on creditors since entities pay to suppliers and other creditors after a certain time lag. Therefore, the operating cycle duration is considered to start when the entity undertakes to pay for its purchases, rather than upon the fact of money remittance [5, p. 266]. The entity may become bound to pay not only for purchases, but also incur other operating expenses. In this respect, it is worth considering how A.l. Alekseeva ${ }^{2}$ defines the substance of the operating cycle, stating that it is a period of time required for the entity to bind itself to incur production expenses and collect cash from the sale of products and services.

According to another view, which is different from the generally accepted one, the operating cycle should be regarded as the duration of deals with tangible working assets, period of time from the purchase of resources up to the finished product output, that is the inventory period. The idea behind this statement is that many Russian entities can receive prepayments for their products, thus distorting the common perception of the operating cycle.

As for this point of view, I should note that such aggressive financial policy is also typical of businesses from other countries due to the monopolistic nature or other reasons. However, as stated in the existing literature, those countries do not exclude the distribution process from the operating cycle. There is hardly any company in

\footnotetext{
${ }^{1}$ Dybal' S.V. Finansovyi analiz: teoriya i praktika [Financial analysis: theory and practice]. St. Petersburg, Biznes pressa Publ., 2004, 304 p.

${ }^{2}$ Alekseeva A.I., Vasil'ev Yu.V., Maleeva A.V. et al. Kompleksnyi analiz khozyaistvennoi deyatel'nosti [Comprehensive analysis of business performance]. Moscow, KnoRus Publ., 2015, 720 p.
}

Russia, which sells only on a prepayment basis and has no trade receivables. How should the situation be qualified? Shall it be regarded as the operating cycle? In my opinion, some standalone cases or temporary difficulties should not make businesses revise conceptual principles of the existing categories and techniques. It goes without saying that the operating cycle will be equal to the inventory period if the entity sells its products and services only on the prepayment basis.

The cash conversion cycle is the amount of time needed for the entire turnover of monetary capital invested in working assets, from paying for procurement, incurring other operating expenses to collecting cash for products shipped and services delivered. Entities usually lack finance when they face a gap between the maturity of receivables and proceeds from buyers.

Therefore, I should mention the most common inaccuracies found in some authors' definitions of the substance of the cash conversion cycle.

What falters first of all is that the cash conversion cycle is defined as the period of the operating cycle when the entity is financed with its own working capital [4, p. 209; 6, p. 24]. The period is equated to the time of working capital turnover. As a matter of fact, financial needs are satisfied with equity or loans and borrowings ${ }^{3}$.

As for the second inaccuracy, most authors measure the cash conversion cycle by focusing on trade payables, which reduce financial needs to purchase the inventories, rather than the entire trade payables. Moreover, there are no cash flows while other working assets are constructed since many expenses relating to construction in progress, cost of finished products are recognized on an accrual basis, rather than on a payment basis. Thus, determining the length of the cash conversion cycle and needs to finance working assets, in addition to trade payables, it is necessary to consider the average wages payable, social security charges, taxes and levies, deferred income, provision for future expenses and payments, i.e. overall accounts payable, other than

\footnotetext{
${ }^{3}$ Efimova O.V. Finansovyi analiz: sovremennyi instrumentarii dlya prinyatiya ekonomicheskikh reshenii [Financial analysis: Modern tools for economic solutions]. Moscow, Omega-L Publ., 2010, 351 p.
} 
amounts due for transactions with long-term assets. There is also a time lag between the accrual and repayment of liabilities, during which the funds are used in operations, reducing the financial needs.

As for the third inaccuracy, when determining the cash conversion cycle, short-term loans and credit are included into current liabilities in addition to accounts payable. These are sources of finance, which mainly satisfy needs in monetary working capital.

The forth inaccuracy is that the cash conversion cycle is regarded as the time when monetary funds are withdrawn from the circulation [2, p. 10-15; 7, p. 50]. As a matter of fact, they are involved into operations. Money is taken out of operations if it is deposited with bank accounts or works as short-term financial investment.

The economic literature also provides different views on the technique for measuring the length of operating and cash conversion cycles.

According to L.A. Bernstein [8, pp. 407-413], J.C. Van Horne, J.M. Wachowich [5, p. 266], T.P. Carlin, A.R. McMeen ${ }^{4}$, B. Colass ${ }^{5}$, Cheng Lee, J. Finnerty ${ }^{6}$ and others, the length of the operating cycle is gauged as follows:

$$
P_{O C}=P_{I}+P_{A R},
$$

where $P_{l}$ is the amount of time, during which capital is kept as inventories (raw materials, supplies, semifinished products of construction in progress, finished products);

$P_{A R}$ is the amount of time, during which capital is kept as accounts receivable.

The same technique is applied by many Russian authors, such as V.V. Kovalev [9, p. 532], E.S. Stoyanova ${ }^{7}$ N.N. Selezneva, A.F. Ionova ${ }^{8}$,

\footnotetext{
${ }^{4}$ Carlin T.P., McMeen A.R. Analiz finansovykh otchetov (na osnove GAAP) [Analyzing Financial Statements]. Moscow, INFRA-M Publ., 1998, $448 \mathrm{p}$.

${ }^{5}$ Colass B. Upravlenie finansovoi deyatel'nost'yu predpriyatiya. Problemy, kontseptsii i metody [Gestion financière de l'entreprise : problématique, concepts et méthodes]. Moscow, Finansy, YUNITI Publ., 1997, 576 p.

${ }^{6}$ Lee Cheng, Finnerty J. Finansy korporatsii: teoriya, metody i praktika [Corporate Finance: Theory, Method, and Applications]. Moscow, INFRA-M Publ., 2000, 686 p.
}

\section{A.D. Sheremet ${ }^{9}, \quad$ S.N. Morozova $\quad[10, \quad$ p. 81$]$} D.Yu. Busygin [11, p. 48], etc.

The second algorithm for the operating cycle measurement, which is very frequently mentioned in the Russian literature, is as follows:

$$
P_{i}=P_{P I}+P_{C I P}+P_{F P}+P_{A R} \text {, }
$$

where $P_{P I}$ is the amount of time, during which capital is kept as production inventories and materials;

$P_{C I P}$ is the amount of time, during which capital is kept as construction in progress;

$P_{F P}$ is the amount of time, during which capital is kept as stock of finished products;

$P_{A R}$ is the amount time, during which capital is kept as accounts receivable.

This is an augmented model that allows to pinpoint the circulation phase when the working capital turnover accelerates or slows down as part of operations. Its weakness is that prepayments made to suppliers are included into accounts receivable, being less liquid than amounts due from customers. They cannot morph into cash as fast as amounts due from customers. First of all, the entity obtains materials from suppliers, use them for production purposes. It gains income by selling its finished products. Thus, prepayments and retainers are a virtually less marketable working asset. If they are recognized as current receivables, this extends the time they are held for sale of products and concurrently reduces the duration of the inventory period. In this respect, O.V. Efimova [12, p. 167] quite reasonably distinguishes prepayments to suppliers in the operating cycle $-P_{\text {adv }}$ :

$$
P_{O C}=P_{A d v}+P_{P I}+P_{C I P}+P_{F P}+P_{A R} \text {. }
$$

Likewise the length of the operating cycle shall be decreased by the time, during which it is served with customers' prepayments. However, scholars dissent from this statement. As some scholars opine,

\footnotetext{
${ }^{7}$ Finansovyi menedzhment: teoriya i praktika [Financial management: Theory and practice]. Moscow, Perspektiva Publ., 2002, 656 p.

${ }^{8}$ Selezneva N.N., Ionova A.F. Finansovyi analiz. Upravlenie finansami [Financial analysis. Financial management]. Moscow, YUNITI-DANA Publ., 2003, 639 p.

${ }^{9}$ Sheremet A.D., Ionova A.F. Finansy predpriyatii: menedzhment $i$ analiz [Corporate Finance: Management and Analysis]. Moscow, INFRA-M Publ., 2008, 479 p.
} 
customers' prepayments reduce the time capital is held for sale of products. The same is true for the operating cycle respectively. According to other authors [11, p. 44; 13, p. 97-98] who I agree with, prepayments have no impact on the length of the operating cycle. Like accounts payable, they decrease financial needs, i.e. shorten the cash conversion cycle. Unlike retainers given to suppliers, which are treated as capital expenditures for corporate assets extending, under other conditions being equal, the cash conversion cycle, I believe prepayments from customers should be regarded as a source of operational finance reducing the cash conversion cycle.

Models (1)-(3) characterize the capital turnover directly as is in the operating process. In the mean time, working assets include funds that do not directly relate to the phases of production and product sale. First of all, it concerns cash and cash equivalents, short-term financial investment, which are temporarily out of corporate circulation. Operations are also indispensable without some cash reserve. Thus, determining the duration of the operating process, I.A. Blank [1, p. 275], L.S. Vasil'eva and M.V. Petrovskaya ${ }^{10}$, M.A. Vakhrushina, N.S. Plaskova ${ }^{11}$, T.V. Timofeeva ${ }^{12}$ consider the average time capital is held as balance with banks and short-term financial investment, i.e. $P_{M A}$ :

$$
P_{O C}=P_{P I}+P_{C I P}+P_{F P}+P_{A R}+P_{M A} \text {. }
$$

I share the point of view expressed by O.V. Efimova $[12$, p. 170], E.A. Gudkova [14, p. 51] stating that the algorithm can be used to analyze each element of the turnover time of comprehensive capital invested in current assets. Its duration will be longer than the cash conversion cycle. Funds held with banks for a long time or as short-term financial investment inhibit the capital turnover as a whole and working capital in particular. However, they do not influence the length of the operating and cash conversion cycles.

\footnotetext{
${ }^{10}$ Vasil'eva L.S., Petrovskaya M.V. Analiz khozyaistvennoi deyatel'nosti [Analysis of business performance]. Moscow, KnoRus Publ., 2016, 606 p.

${ }^{11}$ Analiz finansovoi otechetnosti [Analysis of financial statements]. Moscow, Vuzovskii uchebnik Publ., 2007, 367 p.

${ }^{12}$ Timofeeva T.V. Analiz denezhnykh potokov predriyatiya [Analysis of corporate cash flows]. Moscow, Finansy i Statistika Publ., 2010, 368 p.
}

As for the length of the cash conversion cycle $P_{\text {ccc }}$ that is the cycle of monetary capital circulation, all the authors unanimously surmise that it is shorter than the operating process due to the period, when the operating cycle is served with creditors' funds $P_{A P}$.

The cash conversion cycle can also be negative if accounts payable cover financial needs of the operating cycle. In this case, as V.M. Purlik notes, the corporate operating cycle turns into a cash pipeline [15, p. 244]. According to O.V. Efimova, the situation is quite probable in the case of trading and servicing businesses ${ }^{13}$.

The model for gauging the cash conversion cycle length can be formalized as follows:

$$
P_{C C C}=P_{O C}-P_{A P}
$$

or

$$
P_{C C C}=P_{I}+P_{C I P}+P_{F P}+P_{A R}-P_{A P} \text {. }
$$

The models represent a general approach to calculating the cash conversion cycle, when settlements with customers and suppliers are based on the credit scheme.

Therefore, some customers make prepayments, while some suppliers require them. In this case, it is possible to use the augmented model of the cash conversion cycle in line with the period of prepaid expenses turnover $P_{P E}$ and the period when the operating cycle is served with customers' prepayments $P_{C P}$ :

$$
P_{C C C}=P_{P E}+P_{I}+P_{C I P}+P_{F P}+P_{A R}-P_{A P}-P_{C P} \text {. }
$$

I agree with N.O. Kozlova and T.P. Markeeva $[16$, p. 92] who unfold the model splitting the period, when the operating cycle is financed with creditors' funds, in two components:

- the period when the operating cycle is served with suppliers' funds $P_{\text {suppli }}$

- the period when the operating cycle is served with other creditors' funds $P_{\text {cred. }}$.

$$
P_{C C C}=P_{P E}+P_{I}+P_{C I P}+P_{F P}+
$$

$+P_{A R}-P_{\text {Suppl }}-P_{\text {Cred }}+P_{C P}$.

\footnotetext{
${ }^{13}$ Efimova O.V. Finansovyi analiz: sovremennyi instrumentarii dlya prinyatiya ekonomicheskikh reshenii [Financial analysis: Modern tools for economic solutions]. Moscow, Omega-L Publ., 2010, 351 p.
} 
Table 1 depicts constituents of the operating and cash conversion cycles.

The operating cycle management mainly relates to technology and marketing, without being a part of financial management, while its financial sources and their formation are within the scope of financial management. However, they should be regarded through their correlation and mutual dependence. Managers of both disciplines should have a clear understanding of their economic substance and calculation techniques.

It is noteworthy that scholars seriously dispute not only constituents of the operating and cash conversion cycles but also the technique to calculate summands of the models.

Most literature sources suggest treating the capital turnover period at certain phases of the operating cycle through the ratio of the average balance of some working assets to:

- average sales per day;

- average daily cost of products sold;

- average daily credit turnover of corresponding constituents of working assets which pass to the following phase of the operating cycle.

If based on different methods, the calculations of turnover period will seriously diverge.

M.N. Dokuchaeva suggests the first and second type of indicators should be called partial given they are based on revenue or cost of products sold, while the third type is meant to be individual [17, p. 8]. A.D. Sheremet, R.S. Saifullin and E.V. Negashev ${ }^{14}$ call them summands and partial. I believe the first and second types of indicators had better be called constituents since they have a common denominator and can be summed, while the second type is partial. Constituents totally make the general indicator of the working capital turnover in the operating cycle:

- based on revenue:

$$
\frac{P E \cdot G}{\operatorname{Rev}}+\frac{I \cdot G}{\operatorname{Rev}}+\frac{C I P \cdot G}{\operatorname{Rev}}+
$$

\footnotetext{
${ }^{14}$ Sheremet A.D., Saifullin R.S., Negashev E.V. Metodika finansovogo analiza [Financial analysis technique]. Moscow, INFRA-M Publ., 2002, $202 \mathrm{p}$.
}

$+\frac{F P \cdot G}{\operatorname{Rev}}+\frac{A R \cdot G}{\operatorname{Rev}}=\frac{W A \cdot G}{\operatorname{Rev}}$

- based on the cost of products sold:

$$
\begin{aligned}
& \frac{P E \cdot G}{\operatorname{Cost}_{P S}}+\frac{I \cdot G}{\operatorname{Cost}_{P S}}+\frac{C I P \cdot G}{\operatorname{Cost}_{P S}}+ \\
& +\frac{F P \cdot G}{\operatorname{Cost}_{P S}}+\frac{A R \cdot E R \cdot G}{\operatorname{Cost}_{P S}}=\frac{W A \cdot G}{\operatorname{Cost}_{P S}}
\end{aligned}
$$

where $P E$ is prepaid expenses;

Cost $_{p s}$ shall mean the cost of products sold;

I is the average balance of inventories;

CIP is the average backlog of construction in progress;

FP is the average stock of finished products;

$A R$ is the average balance of accounts receivable for profit-making activities;

$E R$ is the efficiency ratio of products and services (the ratio of the cost of products sols and gross revenue);

$W A$ is the average amount of working assets in the operating process.

Comparing the turnover indicators made of the constituents as they develop or with benchmarks, it is possible to trace the phase when the turnover of working capital invested in operations slows down or accelerates.

The operating cycle under the model can be endlessly specified to clarify how each type of inventories, semi-finished products, finished products, customers influences the time of working capital turnover.

As many authors note, the formula for decomposing the total duration of working capital turnover by constituent is correct in its general presentation since the real turnover of certain constituents can be assessed through the turnover of a specific constituent, rather than the total revenue.

Therefore, most scholars unanimously suggest using the partial turnover of a respective account, rather than the overall sales turnover in order to measure the time when capital is held at certain phases of the operating cycle (inventories, construction in progress, finished products, accounts receivable). 
However, discrepancies arise anyway arguing what turnover should be taken into account, that of debit or credit? Some authors refer to debit turnover for this purpose. For example, J.C. Van Horne [5, p. 260263], L.A. Bernstein [8, p. 407], L.V. Prykina ${ }^{15}$, etc.

Other authors, such as O.V. Efimova [12, p. 152], S.B. Barngol'ts [18], J. Richard [19, p. 202], N.A. Rusak [20, p. 134], whose opinion I support, tend to the opposite idea. For instance, O.V. Efimova states that it is necessary to handle amounts debited from the account, i.e. those ones recognized as credit of active accounts (since the debit turnover characterizes how property is accumulated or an increase in customers' liabilities) [12, p. 152]. If generally presented, at certain phases of the circulation the algorithm for calculating partial metrics of capital turnover can be expressed as follows:

Turnover period $=$ (Average account balance * Duration) / Credit turnover for the period

In this formula, the average balance constitutes a chronological value of certain assets, which are carried on a specific account.

The turnover is understood as the value of credit turnover on the corresponding account for the analyzable period:

- in the case of construction in progress, credit turnover of the Core Operations account, which shows the factual cost of finished products manufactured in the reporting period;

- in the case of inventories, credit turnover of the Materials account, i.e. their factual use for product output, which is not equivalent to tangible costs since they include the cost of electric power, thermal power, gas, which is not covered with an allowance;

- in the case of the stock of finished products, the cost of products shipped to customer (credit turnover of the Finished Products accounts);

- in the case of accounts receivable, it relates to the amount of accounts receivable which were

\footnotetext{
${ }^{15}$ Prykina L.V. Ekonomicheskii analiz predpriyatiya [Economic analysis of an entity]. Moscow, Dashkov i K Publ., 2016, 256 p.
}

repaid for the reporting period (credit turnover of trade receivables).

The computations in Table 2 demonstrate the difference in the duration of the inventory and operating cycles, depending on the base they are calculated on, i.e. revenue, cost of sales or partial turnover passing to the following phase of the operating cycle.

The difference relates to the inventory period only since the accounts receivable period depends on the ratio of the average outstanding balance to sales per day.

If measured through turnover constituents based on revenue, cost of products sold, partial turnover, the length of the inventory period is 67.6 days, 83.8 days and 109.7 days respectively.

If partial metrics of capital turnover are based on revenue from sale of products, their totality will match the overall period of the inventory period:

$$
\begin{aligned}
& P_{O C}=\frac{18,762 * 360}{99,925}=67.6 \text { days } \\
& P_{O C}=35+14.2+18.4=67.6 \text { days } .
\end{aligned}
$$

They will coincide if computed through the cost of products sold:

$$
\begin{aligned}
& P_{O C}=\frac{18,762 * 360}{80,600}=83.8 \text { days; } \\
& P_{O C}=43.4+17.6+22.8=83.8 \text { days. }
\end{aligned}
$$

In the mean time, it is impossible to sum partial metrics of capital turnover at some phases of the operating cycle, which are measured through interim turnover, since they do not have a common denominator.

$$
\begin{aligned}
& \frac{9,750 * 360}{49,960}+\frac{3,942 * 360}{84,168}+\frac{5,105 * 360}{80,600}+ \\
& +\frac{7,772 * 360}{99,925} \neq \frac{26,534 * 360}{99,925} .
\end{aligned}
$$

However, the error is quite widely spread ${ }^{16}$. First of all, metrics should be converted to the lowest common denominator through the percentage of all

\footnotetext{
${ }^{16}$ Savitskaya G.V. Kompleksnyi analiz khozyastvennoi deyatel'nosti predpriyatiya [Comprehensive analysis of corporate business operations]. Moscow, INFRA-M Publ., 2016, 608 p.
} 
the partial turnovers in the total turnover (revenue or cost of products sold) and subsequently summed up:

$$
P_{O C}=\sum P_{T_{i}} * \text { Percentage }_{i}+P_{A R} \text {. }
$$

Let us do this calculation with figures given in Table 2, referring to the percentage of partial turnover in the total turnover:

a) revenue from sale of products and services:

$$
\begin{aligned}
& P_{O C}=\frac{70 * 49,960}{99,925}+\frac{16.9 * 84,168}{99,925}+ \\
& +22.8 * \frac{80,600}{99,925}+28=70 * 0.5+16.9 * 0.842+ \\
& +22.8 * 0.807+28=35+14.2+18.4+28= \\
& =95.6 \text { days }
\end{aligned}
$$

b) manufacturing cost of products sold and services provided:

$$
\begin{aligned}
& P_{\text {OC }}=\frac{70 * 49,960}{80,600}+\frac{16.9 * 84,168}{80,600}+ \\
& +\frac{22.8 * 80,600}{80,600}+28= \\
& =70 * 0.62+16.9 * 1.004+22.8+ \\
& +28=43.4+17.6+22.8+28=111.8 \text { days. }
\end{aligned}
$$

As we can see, after partial metrics of capital turnover are converted to a common denominator through the percentage of interim turnovers in the total turnover (revenue or cost of products sold), this gives the same result as the direct method does. However, the calculation procedure gets much more complicated.

The divergence of partial and general metrics are especially visible when their dynamics and trends are observed (Table 3).

If capital turnover is evaluated through partial metrics, the duration of the operating cycle decreases by 3.8 days, whereas it increases by 12.8 days if measured through general ones. Capital turnover is seen to accelerate at the initial phases, but the shipment of finished products and collection of receivables subsequently slows down. Therefore, the total turnover slightly rises from RUB 99,925 thousand to RUB 100,500 thousand, i.e. only 0.6 percent, while the average amount of working assets spiked by 14 percent in the operating cycle.

Turnover may speed up at any phase of the operating cycle as the average balance of working assets drops or partial turnover rises passing to the following phase. Capital had better flow from one phase of the operating cycle to another one simultaneously. If turnover accelerates at one phase and slows down at the other, this deteriorates the effect of capital speeding up at the initial phases.

If at any phase of the production cycle the entity's output is higher than the demand, this will generate surplus inventory at the following phases of production. Products are stored until the following phase of production is launched. As a result, the value creation process loses momentum at one line and stretches out due to construction in progress, stocks of finished products, etc. [21, p. 63-65].

So, partial metrics of capital turnover cannot be used to determine the length of the operating cycle. In the mean time, they should not be underestimated as an efficient tool that production and commercial units may rely on in operational management of inventories and accounts receivables. Analyzing partial (local) metrics of turnover, it is possible to quickly identify what changes the speed of capital turnover at certain phases of the operating cycle and influences the withdrawal of capital from the circulation by leveraging inventories and receivables. They can be linked with general indicators through a set of capital mobility or a condensed technique by multiplying their values times the percentage of partial turnover in the total turnover.

It is necessary to clarify which calculation option is more reasonable - revenue or cost of products sold.

As mentioned above [22, p. 981-996], there are differing opinions in literature. Whereas revenue includes not only the cost of resources consumed, but also a portion of the cost of surplus products, some authors opine that it overstates capital turnover indicators. Thus, the cost of products sold would be better to use for the calculation. 
Other authors tend to the opposite idea stating that, if entities with the increasing cost of products use it to measure the working capital turnover, it will raise the turnover ratio, i.e. the length of one turnover round will fall by days. If the cost of products decreases, the turnover will slow down and a turnover round will take more days ${ }^{17}$.

In my opinion, both groups of authors are not very convincing. The rise in the cost of products cannot accelerate the capital turnover since this boosts not only the turnover volume, but also the average balance of working assets, such as construction in progress, cost of finished and shipped products.

Advocates of the revenue technique also fail to provide the sound rationale. As they say, revenue inflates turnover metrics. The scholars overlook the fact that the cost of surplus product raises not only the turnover volume but also the average amount of corporate assets. Therefore, revenue can be used to measure the speed of the comprehensive capital turnover and working capital, in particular.

Trying to determine the duration of the operating cycle and its constituents - inventory period and accounts receivable period, we face another issue because numerators and denominators of the calculation models are not comparable since inventories are recognized in the balance sheet at cost, while accounts receivable are recognized at the selling price.

The operating cycle through revenue:

$P_{O C}=$ Average balance of current assets in the operating cycle (inventories and receivables) / Daily revenue from payments;

$P_{O C}=26,534 /(99,925 / 360)=95.6$.

The operating cycle through the cost of products sold: $P_{O C}=$ Average balance of current assets in the operating cycle (inventories and receivables) / Daily sales through the cost;

$P_{O C}=26,534 /(80,600 / 360)=118.5$.

As I see it, the optimal solution can be found if the length of the operating cycle is calculated on

\footnotetext{
${ }^{17}$ Ermolovich L.L. Analiz khozyaistvennoi deyatel'nosti predpriyatii [Analysis of corporate business operations]. Minsk, Sovremennaya shkola Publ., 2006, 736 p.
}

the phase-by-phase basis through model (1), as widely used in the Western practices:

$$
P_{\text {OC }}=P_{I}+P_{A R} \text {, }
$$

where $P_{l}$ is the amount of time, during which capital is kept as inventories (raw materials, supplies, semifinished products of construction in progress, finished products);

$P_{A R}$ is the amount of time, during which capital is kept as accounts receivable.

Whereas,

$P_{I}=\frac{\text { Average inventory stock } * \text { Days of the period }}{\text { Cost of products sold }}=$ $=\frac{18,762 * 360}{80,600}=83.8$ days ;

$P_{A R}=\frac{\text { Average debts } * \text { Days of the period }}{\text { Revenue from sales on credit }}$.

The operating cycle will totally last 111.8 days $(83.8+28)$.

It is noteworthy that the technique for the phasebased calculation of the operating cycle is quite elaborate because it ensures the comparability of the numerators and denominators in the algorithm used to measure the inventory period and accounts receivable period. Inventories recognized at cost are split into the cost of products shipped and accounts receivable, which are expressed as selling prices and divided by revenue from sales on credit. Both indicators have a different base. According to L.A. Bernstein, the total length of the operating cycle depends on the mutually related indicators [8, p.417]. In this case there is no need to adjust accounts receivable and revenue from sale of products by the gross profitability and VAT since they are equally flexible and resilient to changes in these factors. Reducing the revenue and average balance of accounts receivable by gross income (in this case, 19.34 percent $((99,925-80,600) / 99,925)$, we arrive at the same result as was before the adjustment:

$$
\begin{aligned}
& P_{A R}=\frac{7,772(1-0.1934) 360}{99,935(1-0.1934)}= \\
& =\frac{6,269 * 360}{80,600}=28 \text { days. }
\end{aligned}
$$


Hence, the technique for the phase-based calculation of the operating cycle time seems to be the most reasonable and sound. In this case, there is no room for discussing the non-comparability of the numerator and denominator in the calculation algorithm.

The operating cycle time can be analyzed more profoundly by studying the time it takes an entity to renew each type of raw materials, supplies, semifinished products, finished products, and time it takes to collect amounts due from key customers, using partial metrics of turnover.

The production inventory turnover period (supplies and materials) equals the time production inventories are stored from the date they are accepted for storage until the date they are transferred to the production phase. The shorter this period, under all other conditions being equal, the shorter the production and commercial cycle and the lower the need in working capital. It is calculated by dividing the average stock of materials by daily consumption of respective material. The result should be compared with the benchmark.

The actual duration of inventory turnover is much higher than the benchmark as a whole and by type of materials. The stock of material $C$ is intended to suffice during 2.5 years, being tenfold as high as the benchmark. This is evidence that inventories are not very well managed in the reporting period (Table 4).

The inventory turnover may decelerate as surplus, unmarketable, long-unused materials are accumulated, and additional inventories are purchased as the entity may expect a growth in the inflation rate and shortage of the materials in pursuit of its operations security.

To identify how much each type of materials influences the average period capital is held at this phase, it is necessary to multiply the change in the period, during which capital is held as the stock of materials $i$, times the factual percentage of each one in the total daily turnover of inventories:

$$
\begin{aligned}
& P_{I}^{\text {Part }}=\Sigma \Delta P_{i} * \text { Percentage }_{i 1}=14 * 0.1576- \\
& -5 * 0.351585+810 * 0.002161 \ldots= \\
& =2.2-1.76+1.75 \ldots=10 \text { days. }
\end{aligned}
$$

To evaluate what impact each type of materials has on the total length of the operating cycle, the results should be multiplied by the percentage of materials consumed in the cost of products sold (in this case, they should be multiplied by $0.62(49,960 / 80,600))$.

$$
\begin{aligned}
& P_{I}^{\text {Total }}=\Sigma \Delta P_{i} * \text { Percentage }_{I}=2.2 * 0.62- \\
& -1.76 * 0.62+1.72 * 0.62 \ldots= \\
& =1.36-1.1+1.09+\ldots=6.2 \text { days. }
\end{aligned}
$$

The similar technique is applied to analyze partial indicators of capital turnover in relation to backlog of construction in progress, finished products and outstanding accounts receivable.

Therefore, analysis of partial indicators helps assess the local speed of capital turnover at certain phases of the operating cycle, identify why cash flows slow down and find resources to reduce financial needs of the operating process.

The technique for calculating the cash conversion cycle and its constituents is another topic for discussion. As mentioned above, current assets are formed with equity, borrowings (short-term loans) and debts (accounts payable). As part of operations, financial needs arise from a time gap between the collection of cash and repayment of amounts due. Thus, it is very important to know the period, during which the operating process is served with creditors' funds, including prepayments of buyers.

Overviewing the relevant literature, it is possible to note that the period, during which the operating process is financed with creditors' funds, is measured by comparing the average amount of liabilities with the following indicators:

- the amount of accounts payable discharged in the analyzable period, i.e. debit turnover of creditors' accounts;

- purchase of goods before tax, i.e. credit turnover of creditors' accounts;

- revenue from sale of products;

- cost of products sold.

Such differing opinions emerge because scholars equate the following constructs:

- the time it takes an entity to repay its liabilities; 
- average time needed to extend a commercial loan;

- the period, during which the operating process is financed with creditors' funds.

They are virtually and essentially different. Each of them plays a certain role in financial management.

The first indicator works for measuring the time needed to discharge accounts payable. It is gauged by dividing accounts payable by discharged accounts payable for the analyzable period, i.e. by debit turnover of creditors' accounts. Whereas the fact of payment signifies the completion of accounts payable turnover, amounts of payments remitted to cover debts should be used to measure the period of accounts payable turnover [23, p. 53]. Many authors agree on this point.

The second indicator is mentioned in the Western publications by J.C. Van Horne [5, p. 263], L.A. Bernstein [8, p. 417], J. Richard [19, p. 198], B. Colass ${ }^{18}$ and some other Russian scholars ${ }^{19}$. It is measured by dividing the average accounts payable by average sales per day. It indicates the number of days, for which suppliers grant a grace period, rather than the time it takes an entity to pay off its debts.

In literature the time for repayment of accounts payable and grace period are often regarded as identical concepts.

Their difference is illustrated with the following example.

The opening amount due to suppliers was RUB 4,500 thousand. The entity acquired goods on credit worth RUB 44,200 thousand. During this period, it paid off its debts of RUB 38,460 thousand. The closing amount due was RUB 10,240 thousand. The average amount of the operational loan granted by suppliers is RUB 7,370 thousand $((4,500+10,240) / 2)$.

\footnotetext{
${ }^{18}$ Colass B. Upravlenie finansovoi deyatel'nost'yu predpriyatiya. Problemy, kontseptsii i metody [Gestion financière de l'entreprise : problématique, concepts et méthodes]. Moscow, Finansy, YUNITI Publ., 1997, 576 p.

${ }^{19}$ Finansovyi menedzhment: problemy i resheniya [Financial management: Issues and solutions]. Moscow, Yurait Publ., 2014, 903 p.; Finansovyi menedzhment [Financial management]. Moscow, KnoRus Publ., 2013, 654 p.; Prykina L.V. Ekonomicheskii analiz predpriyatiya [Economic analysis of an entity]. Moscow, Dashkov i K Publ., 2016, 256 p.
}

If the amount is divided by daily purchase on credit, the average loan period granted by suppliers is assessed:

$P_{\text {Grace }}=\frac{\overline{A P}}{\text { Daily purchase on credit }}=$

$=\frac{7,737}{44,200 / 360}=60$ days .

Indeed, the average time for repayment of accounts payable is:

$$
\begin{aligned}
& P_{\text {Grace }}=\frac{\overline{A P}}{\text { Average repayment of AP per day }}= \\
& =\frac{7,370}{38,460 / 360}=69 \text { days } .
\end{aligned}
$$

The period (third indicator) is measured by collating average accounts payable involved in corporate turnover with the cost of products sold. For example, the supplier grants a 60-day grace period. The buyer pays off the debt every 60 days. However, the average outstanding amount due accounts for 20 percent of the total working assets employed in operations. If the operating cycle lasts 180 days, it is financed with creditors' funds for 36 days only. During the remaining 144 days, equity and interestbearing loans are used.

As showed in Table 2, the duration of the operating cycle is 83.8 days. The average balance of working assets in the inventory period is worth RUB 18,762 thousand. Accounts payable make 39.28 percent of working assets $(7,370 / 18,762$ * 100). Hence, the operating cycle is fed with creditors' funds for 32.9 days $(83.8 \times 39.28 \%)$.

If average accounts payable are divided by average sales per day (at cost), the same result is observed:

$$
\begin{aligned}
& P_{\text {Serv }}=\frac{\overline{A P}}{\text { Average sales per day }}= \\
& \frac{7,370}{80,600 / 360}=32.9 \text { days. }
\end{aligned}
$$

The similar technique may help quantify the period, during which the operating cycle is served with buyers' prepayments and other creditors' funds, that is, the ratio of average balances to average sales per day. 
Hence, the operating cycle is financed with equity and borrowings for the remaining period of time. In the above examples, the length of the cash conversion cycle will be

$$
P_{C C C}=P_{O C}-P_{A P}=111.8-32.9=78.9 \text { days. }
$$

If augmented, the length of the cash conversion cycle can be expressed as follows:

$$
\begin{aligned}
& P_{C C C}=\frac{P E}{\text { Cost }_{P S}}+\frac{I}{\text { Cost }_{P S}}+\frac{C I P}{\text { Cost }_{P S}}+\frac{F P}{\text { Cost }_{P S}}+ \\
& +\frac{A R}{\text { Revenue }_{P S}}-\frac{A P}{\text { Cost }_{P S}}-\frac{S P}{\text { Cost }_{P S}} .
\end{aligned}
$$

It is possible to measure the period during which the operating cycle is financed with own working capital. For this, its average value is divided by revenue per day. Some authors erroneously describe the indicators as the speed of equity turnover [6, p. 24]. As a matter of fact, as mentioned above, equity and borrowings, which stream into the operating process, are a part of the overall cash flow, demonstrating the equal speed at each phase of the operating cycle, starting from purchase of inventories to the collection of money from buyers for products, goods and services [22, p. 981-996].

Therefore, scrutinizing the literature, I reveal a significant discrepancy in defining the substance of the operating cycle and cash conversion cycle and setting the calculation technique. The critical analysis underlies the following conclusions.

It is the most reasonable and appropriate option to measure the length of the operating cycle by calculating model (1) on the phase-by-phase basis as the sum of the production cycle duration and accounts receivable turnover.

The duration of the inventory period and its constituents should be gauged by dividing the average stock of materials, backlog of construction in progress and finished product by the cost of products shipped. Assessing the accounts receivable turnover period, it is necessary to collate its balance with the amount repaid per day.

Constituents (summands) and partial indicators can be used to observe the speed of capital turnover at certain phases of the operating cycle. The first type will be appropriate for studying what made the duration of the operating cycle change.
The second one will work in operational management of stocks and accounts receivable for their optimization.

Being used for the local assessment of the working capital turnover at certain phases, partial metrics will not do to determine its duration. First of all, the indicators should be converted to a common denominator by multiplying their values times the percentage of partial turnover, which are accepted for their calculation, in the total turnover (revenue or cost of products sold) and summed up subsequently. The same result will be obtained eventually like the one measured by a direct method, i.e. the ratio of average balance of some working assets to total turnover per day.

Quantifying the duration of the cash conversion cycle, the entity should consider not only commercial credits of suppliers and buyers' prepayments, but also the remaining accounts payable, including payroll liabilities, tax liabilities and others. There is a time lag between the accrual and repayment of liabilities, during which they float in the operating process.

It is practicable to distinguish the time it takes an entity to repay its debts, commercial loan period and period when the operating cycle is served with creditors' funds. They are measured by dividing the average balance of trade payables by the amount repaid per day, average purchase on credit per day, sales per day (at cost of products) respectively. Only the third indicator can be employed to measure the length of the cash conversion cycle.

The cash conversion cycle is served with equity and borrowings (loans). The period, during which the operating cycle is financed with them and depends on their percentage in working assets, should not be equated with the speed of their turnover. If they are added to the general stream, they flow at equal speed throughout the phases of the operating cycle, from purchase to revenue.

To calculate the duration of the operating and cash conversion cycles more precisely, average stock, receivables and payables should be observed by monthly or daily balance, which is even better. It is quite feasible using computer-aided technologies for processing accounting and analytical information. 


\section{Table 1}

Constituents of the operating and cash conversion cycles

\begin{tabular}{|c|c|c|c|c|}
\hline \multicolumn{5}{|l|}{ Inventory period } \\
\hline Prepayments to suppliers & $\begin{array}{l}\text { Stock of resources and } \\
\text { materials }\end{array}$ & $\begin{array}{l}\text { Backlog of construction } \\
\text { in Progress }\end{array}$ & Stock of finished products & Accounts receivable period \\
\hline \multicolumn{5}{|l|}{ Operating cycle period } \\
\hline \multicolumn{5}{|c|}{ Servicing period of the operating cycle } \\
\hline \multirow[t]{2}{*}{ Suppliers' funds } & Other creditors' funds & Prepayments of buyers & Equity & Loans and borrowings \\
\hline & & & \multicolumn{2}{|c|}{ Period of the cash conversion cycle (money turnover cycle) } \\
\hline
\end{tabular}

Table 2

Options to measure the length of the operating cycle, thousand RUB

\begin{tabular}{|c|c|c|c|c|c|c|c|c|}
\hline \multirow[t]{3}{*}{ Assets } & \multirow{3}{*}{$\begin{array}{l}\text { Opening } \\
\text { balance }\end{array}$} & \multicolumn{2}{|l|}{ Turnover } & \multirow{3}{*}{$\begin{array}{l}\text { Closing } \\
\text { balance }\end{array}$} & \multirow{3}{*}{$\begin{array}{l}\text { Average } \\
\text { balance }\end{array}$} & \multicolumn{3}{|c|}{ Turnover period, days } \\
\hline & & \multirow[t]{2}{*}{ Debit } & \multirow[t]{2}{*}{ Credit } & & & \multicolumn{2}{|c|}{ Total turnover } & \multirow{2}{*}{$\begin{array}{l}\text { Partial } \\
\text { turnover }\end{array}$} \\
\hline & & & & & & Revenue & Cost & \\
\hline Stock of materials & 9,500 & 50,390 & 49,960 & 9,930 & 9,715 & 35 & 43.4 & 70 \\
\hline $\begin{array}{l}\text { Construction } \\
\text { in Progress }\end{array}$ & 3,500 & 85,052 & 84,168 & 4,384 & 3,942 & 14.2 & 17.6 & 16.9 \\
\hline Finished products & 3,321 & 84,168 & 80,600 & 6,889 & 5,105 & 18.4 & 22.8 & 22.8 \\
\hline $\begin{array}{l}\text { Total inventories } \\
\text { (inventory period) }\end{array}$ & 16,321 & - & - & 21,203 & 18,762 & 67.6 & 83.8 & 109.7 \\
\hline Accounts receivable & 5,735 & 104,000 & 99,925 & 9,809 & 7,772 & 28 & 28 & 28 \\
\hline Total... & 22,056 & 323,610 & 314,653 & 31,012 & 26,534 & 95.6 & 111.8 & 137.7 \\
\hline
\end{tabular}

Source:Authoring 
Table 3

Comparison of partial and general indicators of capital turnover and their development

\begin{tabular}{|c|c|c|c|c|c|c|c|c|}
\hline \multirow[t]{2}{*}{ Indicator } & \multicolumn{2}{|c|}{$\begin{array}{l}\text { Average balance, } \\
\text { thousand RUB }\end{array}$} & \multicolumn{2}{|c|}{$\begin{array}{l}\text { Credit turnover, } \\
\text { thousand RUB }\end{array}$} & \multicolumn{2}{|c|}{ Length of turnover, days } & \multirow[t]{2}{*}{$\begin{array}{l}\text { Change in the length } \\
\text { of turnover, days }\end{array}$} & \multirow{2}{*}{$\begin{array}{l}\text { Effect of } \\
\text { accelerating } \\
\text { turnover, } \\
\text { thousand } \\
\text { RUB }\end{array}$} \\
\hline & $t_{0}$ & $t_{1}$ & $t_{0}$ & $t_{1}$ & $t_{0}$ & $t_{1}$ & & \\
\hline Stock of materials & 9,715 & 9,200 & 49,960 & 58,300 & 70 & 56.8 & -13.2 & $-2,137$ \\
\hline Construction in Progress & 3,942 & 3,750 & 84,168 & 99,500 & 16.9 & 13.6 & -3.3 & -910 \\
\hline Finished products & 5,105 & 7,500 & 80,600 & 95,250 & 22.8 & 28.3 & 5.5 & 1,467 \\
\hline Accounts receivables & 7,772 & 9,800 & 99,925 & 100,500 & 28 & 35.1 & 7.1 & 1,983 \\
\hline $\begin{array}{l}\text { Sum of partial indicators } \\
\text { of turnover length }\end{array}$ & - & - & - & - & 137.7 & 133.8 & -3.8 & 403 \\
\hline $\begin{array}{l}\text { Length of the operating cycle } \\
\text { (Total turnover) }\end{array}$ & 26,534 & 30,250 & 99,925 & 100,500 & 95.6 & 108.4 & 12.8 & $-3,563.3$ \\
\hline
\end{tabular}

Source:Authoring

Table 4

The period of inventory turnover

\begin{tabular}{|c|c|c|c|c|c|c|}
\hline \multirow[t]{2}{*}{$\begin{array}{l}\text { Type of } \\
\text { inventories }\end{array}$} & \multirow[t]{2}{*}{$\begin{array}{l}\text { Average balance, } \\
\text { thousand RUB }\end{array}$} & \multicolumn{2}{|c|}{$\begin{array}{l}\text { Amount of materials consumed } \\
\text { per day }\end{array}$} & \multicolumn{3}{|l|}{ Stock, days } \\
\hline & & $\begin{array}{l}\text { Thousand } \\
\text { RUB }\end{array}$ & Percentage & Benchmark & Actual & Variance \\
\hline A & 1,400 & 21.875 & 15.76 & 50 & 64 & 14 \\
\hline B & 1,220 & 48.8 & 35.1585 & 30 & 25 & -5 \\
\hline$C$ & 270 & 0.3 & 0.2161 & 90 & 900 & 810 \\
\hline$\ldots$ & $\ldots$ & $\ldots$ & $\ldots$ & $\ldots$ & $\ldots$ & $\ldots$ \\
\hline Total... & 9,715 & 138.8 & 100 & 60 & 70 & 10 \\
\hline
\end{tabular}

Source:Authoring

\section{References}

1. Blank I.A. Upravlenie denezhnymi potokami [Cash flow management]. Kiev, Nika-Tsentr Publ., 2002, 736 p.

2. Krylov S.I. [Methods to analyze current assets of a commercial organization]. Finansovyi vestnik: finansy, nalogi, strakhovanie, bukhgalterskii uchet = Financial Bulletin: Finance, Taxes, Insurance, Accounting, 2010, no. 3, pp. 10-15. (In Russ.)

3. Basharina A.V. [Developing the methodology for defining the operational cycle duration]. Finansovaya analitika: problemy i resheniya = Financial Analytics: Science and Experience, 2012, no. 40, pp. 30-35.

URL: https://cyberleninka.ru/article/v/razvitie-metodologii-opredeleniya-dlitelnosti-operatsionnogo-tsikla (In Russ.)

4. Sukhova L.F., Feronova A.V. [Experimental calculations of working capital efficiency on the consumer cooperation case using the computation algorithms for turnover indices]. Vestnik Belgorodskogo universiteta kooperatsii, ekonomiki i prava = Herald of Belgorod University of Cooperation, Economics and Law, 2013, no. 4, pp. 205-215. (In Russ.) 
5. Van Horne J.C., Wachowich J.M. Jr. Osnovy finansovogo menedzhmenta [Fundamentals of Financial Management]. Moscow, Vil'yams Publ., 2008, 1232 p.

6. Karaeva F.E. [Assessing the business activity of the enterprise on the basis of indicators of asset turnover]. Nauchnye izvestiya, 2017, no. 7, pp. 22-26. (In Russ.)

7. Il'in S.Yu., Kochetkova I.A. [Analyzing the business activity and operating profitability of the enterprise]. 4асопіс еконамічних реформ, 2014, no. 4, pp. 49-55. (In Russ.)

8. Bernstein L.A. Analiz finansovoi otchetnosti: teoriya, praktika i interpretatsiya [Financial Statement Analysis: Theory, Application and Interpretation]. Moscow, Finansy i Statistika Publ., 1996, 624 p.

9. Kovalev V.V. Vvedenie $v$ finansovyi menedzhment [Introduction to financial management]. Moscow, Finansy i Statistika Publ., 2006, 768 p.

10. Morozova S.N. [Analysis of business activity of the organization]. Vestnik Mezhdunarodnogo Instituta upravleniya $=$ Herald of International Institute of Management, 2015, no. 5-6, pp. 80-84. (In Russ.)

11. Busygin D.Yu., Busygin Yu.N. [On the harmony of operating cycle segments]. Bukhgalterskii uchet $i$ analiz $=$ Accounting and Analysis, 2017, no. 12, pp. 41-49. (In Russ.)

12. Efimova O.V. Finansovyi analiz [Financial analysis]. Moscow, Bukhgalterskii uchet Publ., 2002, 528 p.

13. Kogdenko V.G. Metodologiya i metodika ekonomicheskogo analiza [Methodology and methods of economic analysis]. Moscow, YUNITI Publ., 2013, 543 p.

14. Gudkova E.A., Gudkov S.V. Sovershenstvovanie uchetno-analiticheskogo instrumentariya v sisteme upravleniya oborotnymi aktivami sel'skokhozyaistvennykh organizatsii [Perfecting the accounting and analytical tools in the system of current asset management of agricultural organizations]. Minsk, Institute of System Research in Agroindustrial Complex of NAS of Belarus Publ., 2009, 164 p.

15. Purlik V.M. [Operating and financial cycle as drivers of operational business efficiency]. RISK: Resursy, Informatsiya, Snabzhenie, Konkurentsiya = RISK: Resources, Information, Supply, Competition, 2017, no. 1, pp. 243-245. (In Russ.)

16. Kozlova N.O., Markeeva T.P. [Study of the effect of the duration of the operating and financial cycles the financial stability of the enterprises of the Tula region]. Izvestiya Tul'skogo gosudarstvennogo universiteta. Ekonomicheskie i yuridicheskie nauki = Izvestiya TuIGU. Economic and Legal Sciences, 2016, no. 1, pp. 91-98. (In Russ.)

17. Dokuchaeva M.N. [Assessment of assets and capital turnover]. Sistemnoe upravlenie, 2013, no. 3, pp. 1-8. (In Russ.) URL: http://sisupr.mrsu.ru/2013-3/PDF/dokuchaeva_m_n_statya.pdf

18. Barngol'ts S.B., Sukharev A.M. Oborotnye sredstva promyshlennykh predpriyatii (obrabatyvayushchei promyshlennosti) [Current assets of industrial enterprises (manufacturing industry)]. Moscow, Gospolitizdat Publ., 1957, 392 p.

19. Richard J. Audit i analiz khozyaistvennoi deyatel'nosti predpriyatiya [Analyse financière et audit des performances]. Moscow, Audit, YUNITI Publ., 1997, 375 p.

Please cite this article as: Savitskaya G.V. Updating the Existing Approaches to Gauging the Length of Operating and Cash Conversion 
20. Rusak N.A., Rusak V.A. Finansovyi analiz sub"ekta khozyaistvovaniya [Financial analysis of a business entity]. Minsk, Vysheishaya shkola Publ., 1997, 309 p.

21. Liker J.R. Dao Toyota: 14 printsipov menedzhmenta vedushchei kompanii mira [The Toyota Way: 14 Management Principles from the World's Greatest Manufacturer]. Moscow, Al'pina Biznes Buks Publ., 2006, $400 \mathrm{p}$.

22. Savitskaya G.V. [Problematic Aspects of Calculating the Capital Turnover Indicators]. Ekonomicheskii analiz: teoriya i praktika = Economic Analysis: Theory and Practice, 2018, vol. 17, iss. 5, pp. 981-996. (In Russ.) URL: https://doi.org/10.24891/ea.17.5.981

23. Efimova O.V. [Analysis of current assets of the organization]. Bukhgalterskii uchet $=$ Accounting, 2000, no. 10, pp. 47-53. (In Russ.)

\section{Conflict-of-interest notification}

I, the author of this article, bindingly and explicitly declare of the partial and total lack of actual or potential conflict of interest with any other third party whatsoever, which may arise as a result of the publication of this article. This statement relates to the study, data collection and interpretation, writing and preparation of the article, and the decision to submit the manuscript for publication. 